\title{
Economic Load Analysis of Smoker and Non- Smoker Fisherman in Medan City
}

\author{
Destanul Aulia ${ }^{*}$, Sri Fajar Ayu ${ }^{2}$ \\ ${ }^{1}$ Faculty of Public Health, Universitas Sumatera Utara, Medan, Indonesia \\ ${ }^{2}$ Faculty of Agriculture, Universitas Sumatera Utara, Medan, Indonesia \\ *Email: destanul.aulia@usu.ac.id
}

\begin{abstract}
Urban fisherman have low to medium economic income. Limited income for fisherman becomes an economic burden. Fisherman consume cigarettes to the point of addiction, and thus do not prioritize family needs. The research objective was to analyze the economic burden of urban fisherman and compare the economic burden between smoker and non-smoker fisherman. The respondents were 50 smoker fisherman and 50 non-smoker fisherman in Medan Belawan. The research method uses the t test to see the difference in the economic burden of smoker and non-smoker fisherman. The results showed $76 \%$ of smoking fisherman believed that smoking was harmful to health. There is a significant difference between the economic burden between smoking and nonsmoking . The economic expense for a smoker is 42.8\% or IDR846,400 of your monthly income. However, only $8 \%$ of fisherman have health complaints due to smoking. Smokers' priority places cigarettes in second place after basic needs. It is recommended that the government not stop providing knowledge about the evils of smoking to fisherman and stop the entry of cigarettes in fishing areas so it can reduce the economic burden on low-income people.
\end{abstract}

Keywords: Cigarettes, Economy, Income, Expenditure, Poverty

\begin{abstract}
Abstrak
Nelayan perkotaan memiliki pendapatan ekonomi rendah hingga menengah. Penghasilan terbatas pada nelayan menjadi beban ekonomi. Nelayan mengkonsumsi rokok hingga kecandua, dan sehingga tidak memprioritaskan kebutuhan keluarga. Tujuan penelitian adalah menganalisis beban ekonomi nelayan perkotaan dan membandingkan beban ekonomi antara nelayan perokok dan bukan perokok.. Responden adalah 50 nelayan perokok dan 50 nelayan bukan perokok di Medan Belawan. Metode penelitian menggunakan uji t untuk melihat perbedaan beban ekonomi nelayan perokok dan nelayan bukan perokok. Hasil penelitian adalah 76\% nelayan perokok percaya bahwa rokok merusak kesehatan. Ada perbedaan yang signifikan antara beban ekonomi antara nelayan perokok dan bukan perokok. Beban ekonomi perokok adalah 42,8\% atau Rp846.400 dari pendapatan bulanan. Namun, hanya 8\% nelayan memiliki keluhan kesehatan akibat merokok. Prioritas perokok menempatkan rokok di peringkat kedua setelah kebutuhan pokok. Disarankan pemerintah tidak berhenti memberikan pengetahuan tentang keburukan merokok kepada nelayan dan menghentikan masuknya rokok di daerah nelayan sehingga mengurangi beban ekonomi bagi masyarakat berpenghasilan rendah.
\end{abstract}

Kata Kunci:Rokok, Ekonomi, Pendapatan, Pengeluaran, Kemiskinan 


\section{PENDAHULUAN}

\subsection{LATAR BELAKANG}

Masyarakat perokok pada dasarnya menyadari bahwa tembakau merupakan salah satu potensi sumber penyakit yang mengganggu kesehatan. Riset Kesehatan Dasar tahun 2013 mengungkapkan bahwa sebanyak $64.9 \%$ laki-laki dan $2.1 \%$ perempuan berusia di atas 15 tahun merupakan perokok (Kementerian Kesehatan, 2013).

Selain mengganggu kesehatan, konsumsi rokok juga telah menjadi beban ekonomi bagi pengeluaran rumah tangga perokok, khususnya untuk kalangan petani dan nelayan. Petani dan nelayan perkotaan merupakan masyarakat dengan pendapatan menengah ke bawah, pengeluaran untuk rokok akan mengorbankan biaya bagi kepentingan lainnya seperti kebutuhan pokok, kesehatan, dan pendidikan. Kebutuhan keluarga yang seharusnya lebih diutamakan, sering terabaikan, disebabkan oleh perokok yang sudah kecanduan.

Biaya kesehatan yang dikeluarkan Indonesia karena penyakit terkait tembakau mencapai 18,1 miliar USD atau 5,1 kali lipat pendapatan negara dari cukai tembakau pada tahun yang sama (Kosen, S. 2007 Indonesia Report Card). Nelayan perokok membangun image bahwa konsumsi rokok dapat memberikan ketenangan, relaksasi, dan kemampuan lebih dalam bekerja, tanpa memikirkan efek panjang dari kesehatan,dan ekonomi keluarganya. Berdasarkan data Lembaga Demografi Fakultas Ekonomi UI tentang Rumah Tangga Termiskin Terperangkap Konsumsi Rokok (2009), ada 68 \% atau (7 dari 10) rumah tangga di Indonesia yang memiliki pengeluaran pokok untuk membeli rokok.

Pada tahun 2010, beban ekonomi negara akibat rokok mencapai Rp 231,27 triliun. Padahal, pendapatan negara dari cukai tembakau pada tahun itu hanya Rp 55 triliun. Pada tahun 2015, BPJSKesehatan harus mengeluarkan Rp 6,6 triliun hanya untuk penyakit jantung dan pembuluh darah (BPJS, 2015). Rokok juga menyebabkan masyarakat Indonesia kehilangan produktivitas akibat kesakitan (morbiditas), kecacatan (disabilitas), dan kematian (mortalitas) dini. Waktu produktif yang hilang karena rokok diperkirakan mencapai 8,5 juta pada tahun 2015. Lamanya waktu produktif yang hilang ini setara dengan hilangnya Rp 374 triliun dalam setahun.

Kota Medan sebagai Ibukota Provinsi Sumatera Utara ternyata belum memiliki upaya yang tegas dalam melindungi masyarakat dari rokok, konsumsi rokok di kalangan nelayan sehingga akan menjadi beban ekonomi bagi individu perokok, rumah tangga, hingga negara jika tidak ada kebijakan yang mengontrol

\subsection{RUMUSAN MASALAH}

1. Bagaimana beban ekonomi nelayan di kota Medan ?

2. Bagaimana pengaruh beban ekonomi antara nelayan perokok dan bukan perokok di kota Medan?

\subsection{TUJUAN PENELITIAN}

1. Menganalisis beban ekonomi nelayan di kota Medan

2. Menganalisis pengaruh beban ekonomi antara nelayan perokok dan bukan perokok di kota Medan

\subsection{MANFAAT PENELITIAN}

1. Penelitian ini dilakukan dengan harapan agar mengurangi jumlah perokok aktif maupun pasif di kalangan nelayan sehingga masalah-masalah sosial yang ditimbulkan oleh rokok dapat diminimalisir

2. Memberikan solusi yang tepat bagi pemerintah maupun produsen rokok dalam penyaluran informasi terkait bahaya rokok dengan tepat sasaran.

\section{METODE PENELITIAN}


Penentuan lokasi penelitian dilakukan secara sengaja (purposive) karena Medan Belawan merupakan kawasan nelayan di kota Medan. Penelitian ini adalah penelitian survei dengan pendekatan deskriptif analitik dan uji $\mathrm{T}$ independen. Data yang digunakan dalam penelitian ini adalah data primer, yang diperoleh melalui wawancara langsung menggunakan kuesioner kepada responden. Responden adalah 50 nelayan perokok dan 50 nelayan bukan perokok di Medan Belawan (sebagai daerah nelayan di Medan). Data yang terkumpul diolah dengan uji t untuk melihat perbedaan beban ekonomi nelayan perokok dan bukan perokok. Prioritas belanja nelayan perokok dilakukan menggunakan analisis deskriptif dengan SPSS 16. Waktu penelitian dilakukan mulai bulan Juli sampai dengan September 2017.

\section{HASIL DAN PEMBAHASAN}

Berdasarkan hasil wawancara dengan nelayan yang perokok dan bukan perokok, .Reponden dalam penelitian ini adalah nelayan perokok dengan karakteristik :

\begin{tabular}{llcccc}
\hline & Karakteristik & \multicolumn{4}{c}{ Responden } \\
\cline { 2 - 5 } & & \multicolumn{3}{c}{ Nelayan Perokok } & \multicolumn{2}{c}{ Nelayan Bukan Perokok } \\
\cline { 2 - 5 } & & & $\mathbf{n}$ & $\mathbf{n}$ & $\mathbf{0}$ \\
\hline 1. Umur & 3 & 6 & 7 & 14 \\
a. $<25$ & 7 & 14 & 11 & 22 \\
b. 26-35 & 18 & 36 & 15 & 30 \\
c. 36-45 & 20 & 40 & 12 & 24 \\
d. 46-55 & 2 & 4 & 5 & 10 \\
e. $>55$ & & & & \\
Pendidikan & 8 & 16 & 9 & 18 \\
a. SD & 24 & 48 & 18 & 36 \\
b. SMP & 16 & 32 & 14 & 28 \\
c. SMA & 2 & 4 & 9 & 18 \\
d. PT & &
\end{tabular}

Tabel 1. Karakteristik Responden

Dari hasil pada tabel 1, dapat dilihat bahwa rata-rata usia nelayan adalah 36-45 tahun, usia rata-rata nelayan berada pada rentang usia dewasa madya hingga dewasa akhir, hal ini karena pekerjaan nelayan membutuhkan banyak energi dan aktivitas. Meskipun membutuhkan banyak energi dan aktivitas pekerjaan nelayan tidak didukung oleh pendidikan yang baik, karena pendidikan rata-rata pada nelayan dan petani hanya lulusan Sekolah Menengah Pertama (SMP).

\begin{tabular}{lccc}
\hline Variabel & Normalitas Test & T Independent & CI 95\% \\
\hline Produktvitas & $\mathrm{P}=0,706$ & 0,001 & $(0,677-1,923)$ \\
Pengeluaran & $\mathrm{P}=0,355$ & 0,001 & $(6,996-19,014)$ \\
Kerugian & $\mathrm{P}=0,161$ & 0,007 & $(0,273-1,647))$ \\
\hline
\end{tabular}

Tabel 2. Hasil Uji T Independen Nelayan Perokok dan Bukan Perokok

\begin{tabular}{llrrr}
\hline \multicolumn{1}{c}{ Group Statistics } & \multicolumn{2}{c}{} \\
& Nelayan & N & \multicolumn{2}{c}{ Mean } \\
Pendapatan Bulanan & & 50 & & 240,60 \\
& Bukan Perokok & Perokok & 50 & 241,80 \\
\hline
\end{tabular}

Tabel 3. Perbandingan Pendapatan Nelayan Perokok dan Bukan Perokok 
Berdasarkan tabel 2 dan tabel 3, kita dapat melihat bahwa ada pengaruh yang signifikan antara produktivitas, hasil, dan kerugian antara nelayan perokok dan bukan perokok dengan $\mathrm{p}<0,05$. Produktivitas untuk nelayan tidak merokok lebih baik daripada perokok, hal ini karena modal yang digunakan oleh nelayan bukan perokok dapat diganti dengan pendapatan bulanan dari pekerjaan, tetapi untuk nelayan perokok, modal untuk bekerja tidak akan kembali sepenuhnya karena telah digunakan untuk merokok. merokok selain dapat merusak kesehatan, meningkatkan beban ekonomi individu, rumah tangga, dan juga negara. Terlebih lagi pengeluaran untuk rokok, akan mengabaikan biaya untuk kebutuhan lainnya yang sesungguhnya lebih penting, seperti pendidikan anak-anak, kesehatan, hiburan, dan lain-lain. Ini sesuai dengan (Susanas) 2015 bahwa pengeluaran untuk rokok mengalahkan pengeluaran untuk beras. Konsumsi rokok ini setara atau bahkan mengalahkan konsumsi total untuk daging, susu, telur, ikan, pendidikan, dan kesehatan.

\begin{tabular}{lcc}
\hline \multicolumn{1}{c}{ Pengeluaran Nelayan } & Nelayan Perokok & $\begin{array}{c}\text { Nelayan Bukan } \\
\text { Perokok }\end{array}$ \\
\hline Kebutuhan Pokok (Nasi/Makanan) & 43.02 & 47.98 \\
Rokok & 42.8 & 0 \\
Pendidikan Anak & 14.01 & 31.21 \\
Kesehatan & 0.22 & 3.87 \\
Hiburan & 0.19 & 8.98 \\
Kebutuhan Lainnya & 0.55 & 7.98 \\
\hline
\end{tabular}

Tabel 4. Pengeluaran Nelayan Perokok dan Nelayan bukan Perokok

Tabel 4 kita dapat melihat bahwa kebutuhan dasar seperti makanan atau nasi hanya memiliki selisih 3,18\% dengan konsumsi rokok bagi petani, dan hanya memiliki selisih 0,22\% dengan konsumsi rokok untuk nelayan. Konsumsi rokok pada nelayan perokok ini menjadi besar salah satunya karena nelayan bekerja di laut, mulai dari malam hingga dini hari, sehingga nelayan dapat membangun image bahwa rokok dapat menjadi suatu kebutuhan yang harus terus tersedia selama bekerja,pendapatan nelayan perokok dan bukan perokok hampir sama, pendapatan rata-rata nelayan bukan perokok adalah Rp 2.412.000 dan nelayan perokok adalah Rp 2.140.000 setiap bulannya, tetapi pendapatan ini sebenarnya tidak sesuai dengan pendapatan minimum regional Kota Medan yaitu Rp 2.528 0,815. Pengeluaran untuk rokok ini sangat merugikan nelayan karena rokok sebenarnya hanya memberikan sensasi sementara bagi nelayan perokok, dan konsumsi rokok dalam jangka waktu tertentu akan menjadi beban ekonomi bagi individu, rumah tangga, dan negara. Konsumsi rokok untuk nelayan harus menjadi perhatian pemerintah, ini karena konsumsi rokok telah menduduki peringkat kedua setelah kebutuhan dasar, ini mengalahkan kebutuhan lain yang sebenarnya lebih penting seperti pendidikan anak dan

\section{Group Statistics}

\begin{tabular}{lcc}
\hline \multicolumn{1}{c}{ Farmers } & N & Health Complaint \\
\hline Bukan Perokok & 50 & 0 \\
Perokok & 50 & 4 \\
\hline
\end{tabular}

kesehatan

Tabel 5. Keluhan Kesehatan Nelayan Perokok dan bukan Perokok

Tabel 5 menunjukkan bahwa nelayan perokok mempunyai keluhan kesehatan,sedangkan untuk nelayan bukan perokok tidak mempunyai keluhan kesehatan. Hal ini mengingatkan bahwa rokok merupakan hal yang berbahaya bagi kesehatan dan merugikan/beban ekonomi keluarga.

Konsumsi rokok merupakan salah satu faktor risiko utama terjadinya berbagai penyakit tidak menular seperti penyakit jantung koroner, stroke, kanker, penyakit paru kronik dan diabetes mellitus 
dan merupakan penyebab kematian utama di dunia, termasuk di negara kita Indonesia. Konsumsi rokok membunuh satu orang setiap detik. Penelitian epidemiologi tembakau di dunia menunjukkan tembakau membunuh lebih dari lima juta orang setiap tahunnya. Selain menyebabkan gangguan kesehatan, konsumsi rokok juga menyebabkan kerugian ekonomi, baik di tingkat rumah tangga maupun di masyarakat

\section{KESIMPULAN}

1. Beban ekonomi perokok adalah $42,8 \%$ atau Rp846.400 dari pendapatan bulanan. Namun, hanya 8\% nelayan yang memiliki keluhan kesehatan akibat merokok.

2. Ada pengaruh yang signifikan antara beben ekonomi yaitu produktivitas, hasil, dan kerugian antara nelayan perokok dan bukan perokok

\section{UCAPAN TERIMAKASIH}

Semua pihak yang membantu dalam pegabdian masyarakat maupun penelitian wajib dituliskan di bab ccapan terimakasih ini. Tim pelaksana kegiatan pengabdian kepada masyarakat mengucapkan terima kasih kepada nelayan di kawasan Medan Belawan, dan pihak-pihak yang telah membantu dalam penelitian ini sehingga berjalan dengan baik.

\section{DAFTAR PUSTAKA}

Ahsan, A., 2004. Pengaruh Faktor Sosial Ekonomi terhadap Perilaku Merokok Analisa Data Susnass. Tesis tidak di terbitkan, Jakarta: Program pascasarjana Universitas Indonesia

Badan Pusat Statistik. 2014. Survei Sosial Ekonomi Nasional (Susenas) Tahun 2010: Jakarta: Badan Penelitian dan Pengembangan Kesehatan Indonesian Tobacco Control Network,dalam artikel Kerangka Kerja Konvensi dalam Pengendalian Tembakau.

Kusnadi, 2002. Akar Kemiskinan Nelayan. LKIS . Yogyakarta

Mubyarto, 1986, Nelayan dan Kemiskinan Studi Ekonomi di Dua Pantai, CV Rajawali Press, Jakarta.

Notoatmodjo Soekidjo. 2003. Ilmu Kesehatan Masyarakat, Prinsip Prinsip Dasar, Cetakan Kedua.Jakarta: Rineka Cipta.

Kemenkes RI. 2013. Riset Kesehatan Dasar 2013. Jakarta : Kemenkes RI.

Kemenkes RI. 2015. Balitbangkes. Jakarta : Kemenkes RI. World Health Organization., 2013.Tobacco.

World Health Organization, 2015. Indonesia Tobacco Report 